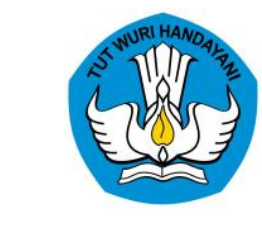

Check for updates
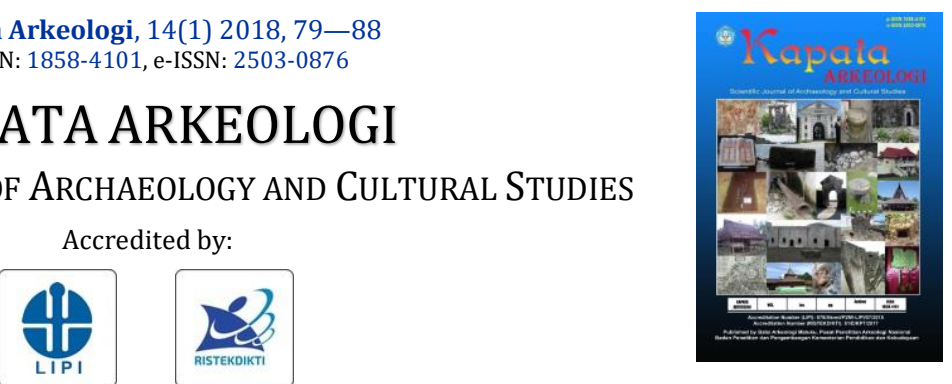

http://kapata-arkeologi.kemdikbud.go.id/

\title{
DORO BATA SITE IN DOMPU, NUSA TENGGARA BARAT: STUDY ON FORM, SPACE, AND TIME
}

\author{
I Nyoman Rema, Ni Putu Eka Juliawati *, Hedwi Prihatmoko \\ Balai Arkeologi Bali \\ J1. Raya Sesetan No. 80, Denpasar 80223, Indonesia \\ *putu.eka@kemdikbud.go.id
}

Received: 01/03/2018; revisions: 07/04 - 06/06/2018; accepted: 06/07/2018

Published online: 31/07/2018

\begin{abstract}
Doro Bata site is a site that has an important value for cultural history of Dompu society, of which traces can still be witnessed to this day. The purpose of this research is to recognize the form, space, and time of Doro Bata Site. Data collection was done through observation by excavation technique, literature study, and interview. The collected data was then analyzed and summarized. Based on the research activities on this site, it can be evident that the Doro Bata Hill is a seven-step terrace (berundak) and a stairway entering from the west, and at the top part was found a structure presumably as the foundation of a building with wooden construction. This site is located on a hill that deserves to be occupied into the settlement given the support of natural resources in the vicinity area. Based on the information from a number of cultural experts and the results of literature studies, it is known that this site was created when Dompu got the influence of Majapahit culture in the $14^{\text {th }}$ century, and allegedly abandoned in the $19^{\text {th }}$ century during the eruption of Mount Tambora.
\end{abstract}

Keywords: Doro Bata; form; space; time

\section{INTRODUCTION}

Research on Doro Bata Site has been implemented for 16 stages until 2018 by Balai Arkeologi Bali (Bali Archaeology Center). This research began with an Islamic research survey in West Nusa Tenggara which was an archaeological research project in Bali. The data was collected by a survey led by Ambary with a team consisting of researchers from the National Archaeological Research Center and Balai Arkeologi Bali in 1978. At that point, Doro Bata received attention due to the local community's belief that on the Doro Bata hill, there was a hole containing privileges i.e. the water can be used to cure diseases, provide safety and fertility (Ambary et al., 1978: 15). Ambary revealed the results of the survey that archaeologically the shape of a hole created on the rocks of the hill was difficult to refer it to yoni although it has a rectangle shape and deliberately carved on hills rock. This hole has a rectangular and rounded central shape. Ambary also found that a few years ago before the survey there were cylindrical stones lying near the stone hole and when the survey was done, the stone no longer existed. It is estimated that the building on the site was built in pre-Islamic times (Ambary et al., 1978: 16).

In 1989 Research Team of Balai Arkeologi Bali initially conducted research on this site and concluded that on the hill where the hole existed, there was terracesshaped building (Suantika et al., 1991: 4). In 1991 it was the second phase of research. The building on Doro Bata Site takes the form of terraces that signify the concept of a prehistoric cultural tradition that continues to evolve before gaining Hindu-Buddhist influence from the Majapahit Kingdom, as a medium of worshiping the forces of nature and ancestral spirits. Having gained Hindu-Buddhist influence, this building was also allegedly used as a medium of worship (Suantika et al., 1991: 6). This conclusion persisted until the study in subsequent years in 2010-2011 they found structures as presumably to be jirat with additional plain and ornate tombstones indicating that the site was also used for burial ground (Ambarawati, 2010: 117; 2011: 7).

In a study of 2016, three structures on the top of Doro Bata's terraced porch (teras berundak) were found, two brick structures and a white-greenish tufa stone (Rema, 2016: 6-8). A study in 2017 sought the continuation of 
the discovered structures in 2016, and found a number of structures, among others: the first structure in the form of a square-footed building foundation, the second structure of 2016 was presumably walls, but in 2017 the conclusion has changed that this was also the foundation structure of the building that two corners has been known by the northwest and northeast corner, and the edge of the structure that leads to the south has not been found. The third structure was thought to be a hall or floor in the middle of the second structure (Tim Penelitian, 2017: 2326). The findings of the structure at Doro Bata Site from several stages of research further affirmed the notion that on this site once stood an important building of its time which at the beginning of its construction was presumed as a worship building, but when it gained the influence of Islam, it was used as a palace. This is because the building was located in high place, with red brick structural materials in large size and they are not easily made or found. The utilization of Doro Bata Site based on the remains discovered from previous research has proven that Doro Bata Site has been utilized from time to time.

Various results of the above study proved that Doro Bata Site is an important site in revealing the cultural history of Dompu Regency in the past that is brimming with values of multicultural, harmony, and identity of the nation. The Doro Bata site has an important value in terms of togetherness and mutual cooperation, which allegedly involves community leaders in implementation of development, customary chiefs in coordinating and leading ceremonies, construction experts and development executing societies in making, locating materials, transporting, and laying stones (Ambarawati, 2007: 123-124). On the other hand, there are more increasing issues around the site. It has been besieged by residential settlements, even it was near to the foot of the hill or the base of terraced porch. This leads to the importance and urgency of this research being undertaken and finalized, that its recommendations of conservation and development can be materialized immediately. The problem formulated in this research is how the form of building on Doro Bata Site? What is the environmental consideration (space) that the site is eligible for shelter? When the site was built, exploited, and abandoned? The general purpose of this research is to reconstruct the history of Indonesian culture especially in Dompu Regency. The specific purpose was to identify form, space, and time of Doro Bata Site. This research was expected to provide a theoretical benefit which was able to explore noble values of the past, and practically can be used to reconstruct the history of culture, cultivate tolerance, and identity of Dompu society.

Previous writings on the belief in mountains, terraced porch as a holy place were ever written by some experts. Sutaba in his article entitled "The Prehistoric Rock
Throne in Bali" outlines that megalithic forms such as terraced porch and stone throne in Prehistoric times serves as a medium of worship for respected leaders, as a medium to maintain good relations between the living and the spirits, and the well-being of the community remains well-preserved. This is confirmed by the notion that the cult of the ancestors found in Indonesia was said to have similarities to that found in Southeast Asia and the Pacific as it is universal and the core of megalithic tradition (Sutaba, 1994: 73-104).

The megalithic belief in the mountain as a force of nature, then becomes one belief in the mountain as the place of ancestral spirits and as the place of the God of the Mountain, this view is not only found in Indonesia but also in Southeast Asia. Such beliefs have great influence on the Indonesian people, not only when the megalithic tradition is expanding rapidly, but much later, in the era of history when the influence of HinduBuddhist Religion, such as in the $15^{\text {th }}$ century of East Java, which regarded Mount Lawu and Penanggungan as a sacred mountain. As it is known in Mount Lawu there are Sukuh and Cetho Temple, each of which has a megalithic style and in Mount Penanggungan there are a number of shrines that have terraced-porches arrangement, as well as Doro Bata. In addition to East Java, in Bali about the 10th century, it also represents such symptom in East Java that regarded the mountain as a sacred place, as a source of prosperity (Sutaba, 1994: 78-80). This paper contributes to the belief in the hill, the mountain as a holy place existed in prehistoric times, until the later times.

Soeryanto in his book entitled The History of Dompu Regency stated that before Dompu had Hindu-Buddhist influence according to the historical record contained in Bo Sangaji Kai, Dompu area was led by Ncuhi or chief of tribe. There are five Ncuhi namely Ncuhi Hu'u, Daha, Saneo, Nowa, and Tonda who still adhere to animistic beliefs and all four have their respective domains (Soeryanto, 2013: 5). The contribution of this study is to provide information that there is a community group that became the forerunner of Dompu people at the present. Based on previous ever-existed writings, none has specifically discussed the form, space, and time of Doro Bata Site which is also a novelty of this research.

Research on Doro Bata Site uses religious theory to solve research problems. Religion is literally interpreted as a behavior that represents a belief, respect, and desire to please a dominating power. Religion serves to reduce anxiety, as it can explain things that humans could not understood. With religion, human beings get the peace to deal with things beyond the reach of his mind, such as death, disaster, disease, and others. Religion can provide answers about the occurrence of the universe, correlation of man to the forces of nature (Prasetyo, 2004: 3). Koentjaraningrat proposed the concept of religion 
broken down into five components that have their own role, but as part of a system is closely related to one another. The five components are: (1) religious emotion, (2) belief system, (3) rites and ceremonies system, (4) ritual and ceremonial equipment, (5) religious people (Koentjaraningrat, 2005: 201-202). However, for Doro Bata Site, it will use the components of belief systems and ritual and ceremonial equipment, including beliefs that have evolved on the site and media of worship such as terraced porch, structures and other equipment such as pottery, tombstones, and others.

\section{MethodS}

Doro Bata site is located in Kampung Kandai Satu area, Kandai Village, Dompu District, Dompu Regency, West Nusa Tenggara Province. Geographically, the Site of Doro Bata is located at the coordinates of $8^{\circ} 47$ '59" South Latitude and $118^{\circ} 23$ ' 36"' East Longitude. The boundaries of its area are to the north of Nae River/Kelurahan Potu, to the south bordering Mbawai Village, to the East bordering with Lepadi Village, and to the west by the Nae River in Karijawa Urban Village (figure 1). Research on the Doro Bata Site is a study with inductive reasoning-hypotheses, i.e. research that begins with observation, measurement, to hypothesis-modeltheoretical form. The data source of this research consists of primary and secondary sources. Primary sources were collected through field observation through excavation and interviews and secondary sources through relevant literature searches. Based on the nature of the data, this type of research is categorized into qualitative research, complemented by the size of the findings.

The analysis of the archaeological findings at the Doro Bata Site was conducted in two ways: (1) an analysis of individual archeological findings, called as specific analyzes; (2) an analysis of a set of findings that takes into account the correlation between artifacts with artifacts, artifacts with features, artifacts with ecofacts, and artifacts with environmental resources, called as context analysis (Simanjuntak et al., 2008: 83).

In addition, in making hypothesis, it used oral history data. Oral history as historical data cannot be overlooked, but its use must still go through a series of studies. Oral history is a verbal message about the past that is transmitted verbally in a period that transcends contemporary generations. In the process of transmission, there is a process of selection and interpretation of a collection of information contained in a verbal message and then transmitted back to the next generation. Therefore, the time profundity of the historical event described in the verbal message (oral history) becomes important, i.e. the longer the time interval of a historical event with the present, the more likely it is to deviate from that history (Vansina, 1985: 29; 191).

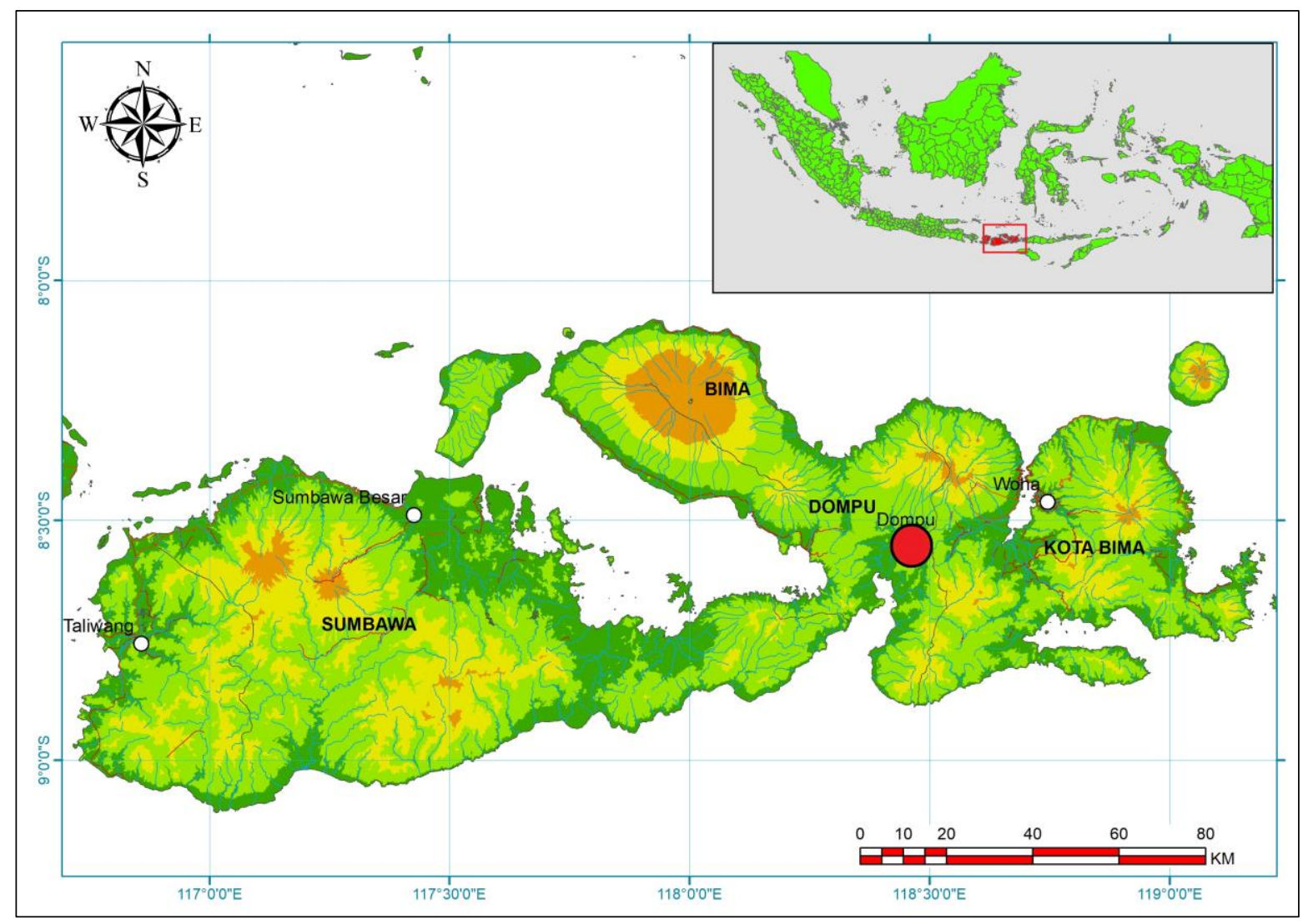

Figure 1. Map of research location, marked by dot

(Source: Basemap from Badan Informasi Geospasial, modified by Authors, 2018) 


\section{RESUlt AND DiscusSion}

\section{Building Form at Doro Bata Site}

Doro Bata site is one of the sites that still keep the mystery that needs to be revealed. Based on the archaeological remains on this site, it indicates the existence of civilization in the past. The remain is a terraced porch structure (teras berundak) formed on a hill, backfilled on the edge and top part using the soil, sand, coral, as a reinforcement. The andesite and tufa boulders are used as retaining slopes and terrace reinforcement, which then over the andesite stone terraces are attached with bricks to form a terraced porch (Suantika et al., 1991: 4). This terraced porch when calculated from a large stone placed at the corner, it is known that the terrace has seven steps, with sizes ranging from $55-80 \mathrm{~cm}$, with a base area of $2718.3 \mathrm{~m}^{2}$; and the peak of $1551,84 \mathrm{~m}^{2}$ (figure 2) with the stairs to the west. This terraced porch is allegedly based on the concept of prehistoric tradition (Sumerata, 2014a: 1-2).

The excavations at the top of the terrace of Doro Bata discovered a wide variety of archaeological remains, dominated by the remains of brick structures of various sizes, fragments of earthenware, pottery, ceramic fragments, charcoal, animal bones, and others. In general, the findings of foundation structure of the building in Doro Bata site were in damaged condition, as the land is unstable. There is an indication of efforts to compress, considering the land where the installation of this structure is the backfill soil transported from the outside,
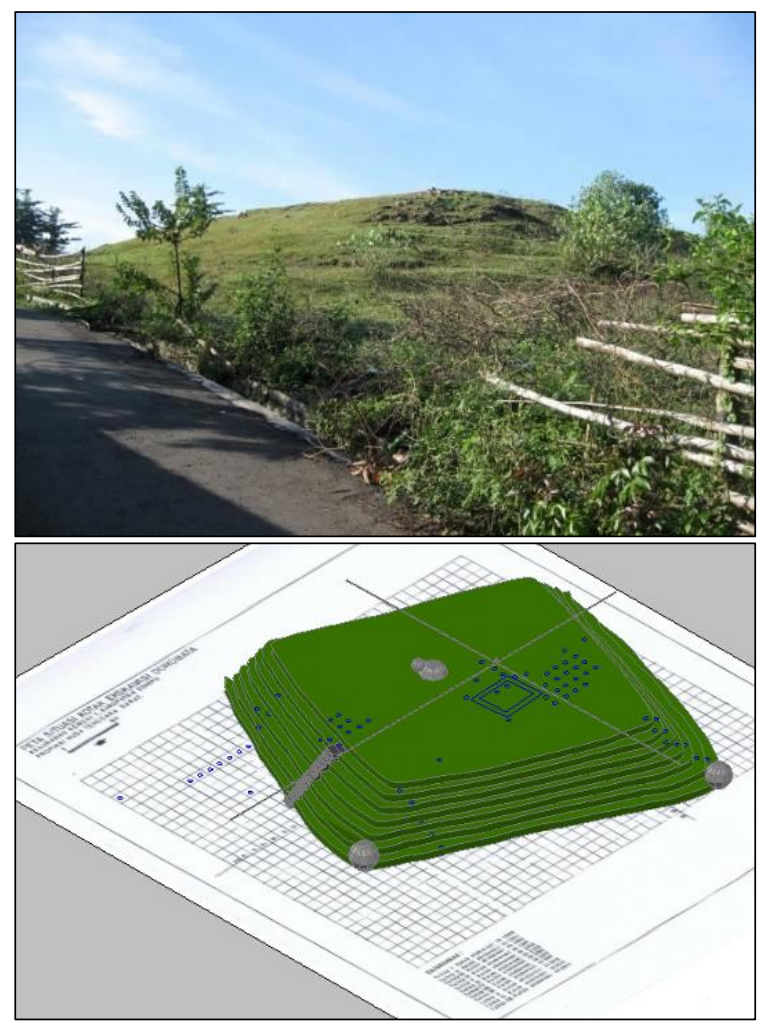

Figure 2. Terraced porch on Doro Bata Site (Source: Balai Arkeologi Bali, 2017)
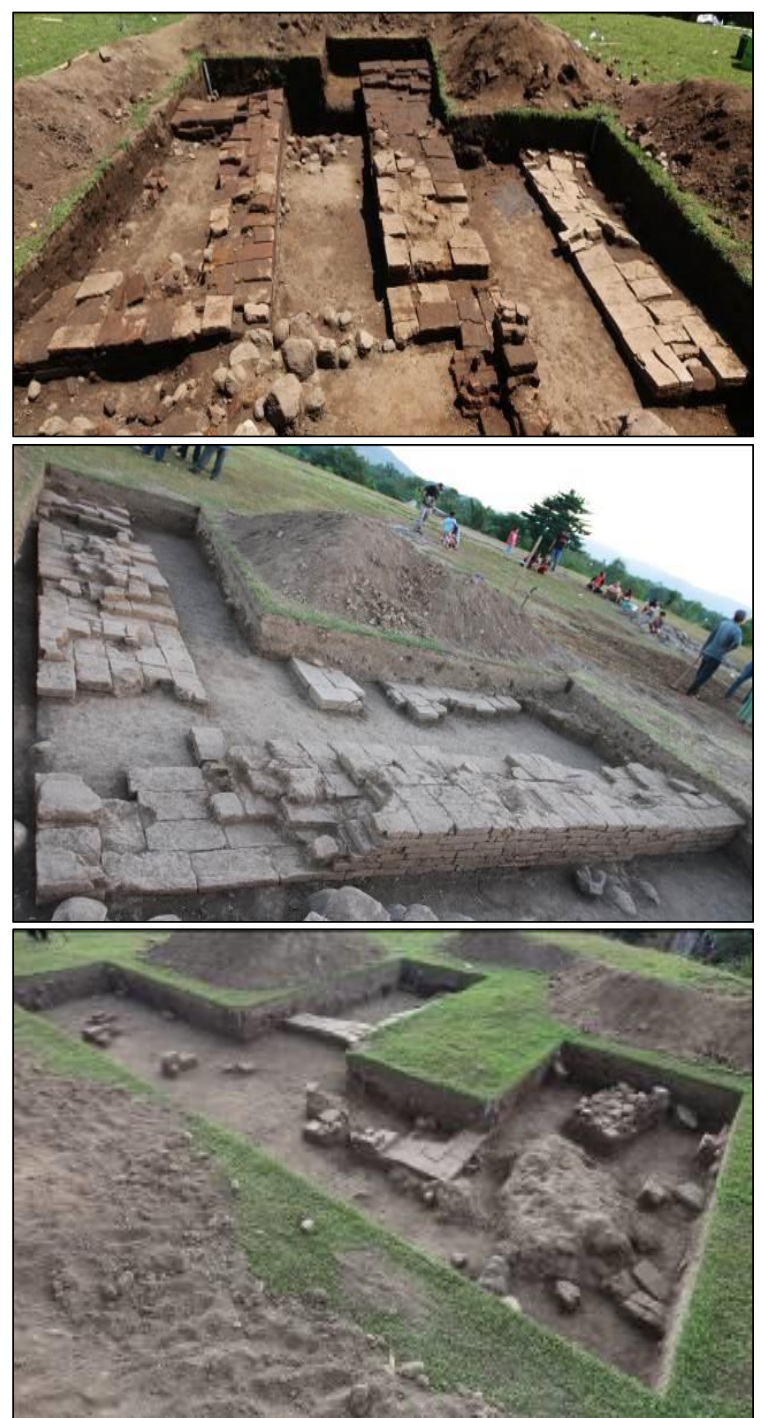

Figure 3. Some Structures in Northeastern Quadrant of Doro Bata

(Source: Balai Arkeologi Bali, 2017)

compacted with sand mixed with gravel, pebbles, and broken bricks.

In the upper center the hole was found by $28 \mathrm{~cm}$ diameter in a rectangular carving measuring $40 \mathrm{~cm}$, and a depth of $72 \mathrm{~cm}$ made on hill rocks that was backfilled into terraced porch, which the water is believed to cure the disease. According to the information of the local community, near the hole was once laying a monolith stone, but it no longer exists. In addition, a brick is found that has a framework, as is commonly found in temple buildings (Suantika et al., 1994: 25) and rectangularshaped structures that resemble a jirat in the center of which there is a plain and ornate tombstone (Sumerata, 2014a: 21). The above opinion indicates a continuous use of the hill according to the time. It is also suspected that the rocks are gradually backfilled, confirmed by the findings of brick structures at a depth of $75 \mathrm{~cm}$, charcoal with the stoves, metal fragments, fragments of uang 
kepeng (dime coin) at a depth of $115 \mathrm{~cm}$ as evidence of human activity.

From the beginning of the research until 2018, this time some foundation structure of the building has been found, which is two square-footed foundation structures, and two more rectangular-shaped foundation structures using bricks that are large enough size with length between $37-38 \mathrm{~cm}, 19-25 \mathrm{~cm}$ in width, and $3.5-6 \mathrm{~cm}$ in thickness. This structure is presumed to be the foundation of the building, and upon it allegedly stands a building with a wooden construction (Tim Penelitian, 2017: 25-26). The structure was found in 2009 in the form of a rectangle at the top of Doro Bata, which is supposedly a building foundation measuring $6.8 \mathrm{~m} \mathrm{x} 7.8$ $\mathrm{m}$ in position to the southwest of the hilltop (Sumerata, 2014a: 13). In 2016 several parts of the structure were found, then continued excavation from 2017 to 2018 found 3 more structures, i.e. two brick structures and a white tufa stone structure.

These three structures are located in the northeast part of the hilltop, with varying sizes, i.e. $4 \times 4 \mathrm{~m}(70 \mathrm{~cm}$ thickness) of brick structure (structure 1), 7.93x6,83m (1m thickness) of brick structure (structure 2), and $3.95 \times 2,75 \mathrm{~m}(65 \mathrm{~cm}$ thickness) (structure 3$)$ of white tufa stones. The structure measuring $7.93 \times 6.83 \mathrm{~m}(1 \mathrm{~m}$ thickness) is presumably to have a framing because during excavation process, almost the whole side of this structure that the bricks laid out obliquely was found. The structure of the tufa (structure 3 ) was positioned in the center of structure 2 which has a distance of $95 \mathrm{~cm}$, which was initially presumed to be the hallway, but it turned out to be the foundation structure of the building which has the privilege of using well-processed tuff rocks in square and rectangle form (figure 3) (Tim Penelitian, 2017: 26-27; 2018: 19-20). In addition to the northeastern quadrant, in 2018 this time the excavation was also conducted in the northwest quadrant, as the excavation has not been done in the section that it is deemed necessary to examine it in order to reveal the remains there. After the excavation, the remains of structures were only found that have not been predicted whether they were foundation structure or other ones, as this structure has been disrupted and only remaining with an area of $2.5 \times 4 \mathrm{~m}$, which only consists of one to two layers. This structure was then attached using clay adhesive, by a brick arrangement of varying sizes, length of $25-45 \mathrm{~cm}$, width of $15-26 \mathrm{~cm}$, thickness of 7-9cm (Tim Penelitian, 2018: 21) (figure 4).

White tufa stone structure was allegedly taken from the source which is still in the form of semi-finished material, formed and mashed near the position of this stone which was the eastern part of the findings' position of this tufa stone structure. This is reasonable as the discovery of white tufa-green waste were existed. Tufa stone is generally composed of a single arrangement

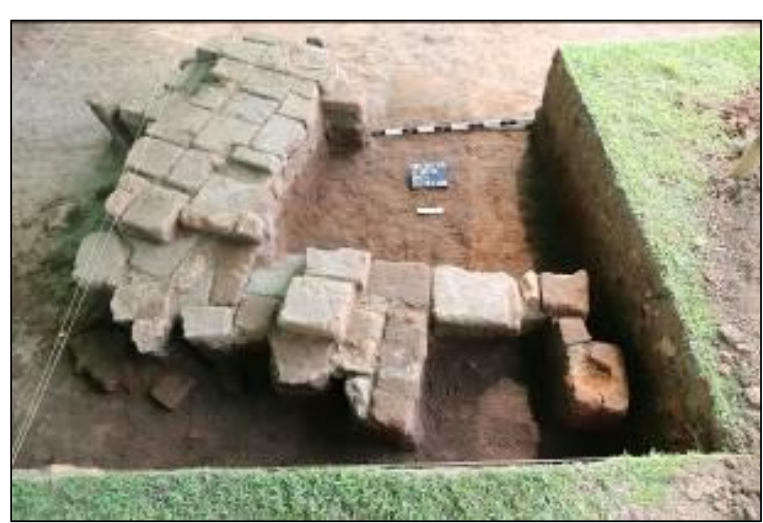

Figure 4. Structure in the Northwest Quadrant of Doro Bata (Source: Balai Arkeologi Bali, 2017)

adjusted horizontally, although there are several parts consisting of two arrangements. This stone is mashed by cutting with tools such as pumice stone and prepared using clay adhesive. Bricks or tuffs stone are damaged and many parts are missing, tufa stones are allegedly still in good condition taken by material seekers, while small pieces are backfilled (Tim Penelitian, 2018: 21).

In the 2018 research this time there was information from cultural observers, historical observers, religious figures, community leaders, and communities around the site when FGDs were held and dissemination that initially the surface of Doro Bata was filled with neatly arranged bricks even though some parts had been damaged. Doro Bata is a sacred and haunted hill that people rarely dare to go up to Doro Bata. According to Rasidin, a teacher at MTs Al Ikhlas Tsanawiyah, in 19671969 people who regarded the bricks and stones abundantly in Doro Bata, they took it for building materials. In 1970 people were prohibited from searching for stones and bricks in Doro Bata and this site had been protected by the state under Dompu County Government and had been installed a sign read "Situs Doro Bata Peninggalan Purbakala" (Doro Bata Archaeological Heritage Site) (Tim Penelitian, 2018: 22).

Regarding the backfill in Doro Bata, it was allegedly taken around the site, this is confirmed by information from the community that in the west of the field (position of the field is on the north side of the site) there is a kind of holes known as old excavations, such as clay mixed with earthenware fragments and ceramic fragments. Backfill in the form of sand and smooth rounded stone allegedly taken from a large river to the north of the site was also suspected to be taken from the beach. Regarding the gravestone found on Doro Bata Site which has Makassar decorative motif, it is allegedly the grave of a sultan, considering Sultan Muhammad Sirajudin I who is the 3rd Sultan of Dompu with the title of Sultan Manuru Bata means Sultan who was buried in Bata in 1667 AD, after the conquest of Makassar over Dompu land. Certainly, this conjecture needs to be investigated further (Tim Penelitian, 2018: 22). 


\section{Environmental Consideration in Establishment of Doro Bata Site}

Doro Bata Hill perceived from its condition now lies in a basin, which is confined by the ranks of the surrounding hills. This is evident in the $\mathrm{U}$ shape of the valley that dynamically forms the morphology of the region and its lithology. The city of Dompu and its surroundings and including the Doro Bata site is located on an alluvium unit consisting of river and beach sediments of gravel, sand to clay. At a glance this hilltop is like a plain with an area of $\pm 1551.84 \mathrm{~m} 2$, in the vicinity there are several sources of springs and rivers such as the river Nae, Silo, and Soa with abundant water which is not directly discharged into the sea, but used for various purposes such as irrigating fish pond, the needs of bathing, washing, irrigating the fertile rice fields of the community and stretching around the site, thus no wonder if the Dompu kingdom in the past was the kingdom who had the main income in rice production (Utomo, 2018: 13).

Selection of high places will be a major consideration to build a palace, because with high places, it is easier to monitor and cope with enemy attacks, both from the land and sea. To the west and south of Bukit Doro Bata which is now a rice field area was once the canal sea of Cempi bay. In addition to a bay canal, in the region there is also a port called Sorebawa. If this data is valid, it means Dompu in the past is a strategic area that has considerable power. This can be proved by Padompo events, mentioned in this event there are three directions to pass through in order to attack Dompu which are Teluk Cempi, Teluk Kempo or Saleh, and Teluk Bima (Rema, 2015: 16).

Related to the environmental considerations of Doro Bata Site as a settlement, it seems to adopt traditional Dompu wisdom through the selection of settlement location by considering the aspects of land rock, land surface, availability of water source and soil fertility known as leka dana (Syafrudin, 2016: 78). This wisdom is the legacy of the selection of settlements from the Ncuhi period in the past as a community leader before Dompu gained the influence of Indian and Islamic culture. From the folk story it is known that in Dompu in the Ncuhi period that was originally the uma or Ncuhi house was built in rectangular and four columns, it was then developed into a nine up to 16 pillars, as a hallmark of social status. The 16-pillars house is the largest house called Uma Ruka. Dompu or Dompo has the 3 periods, namely the Dalu, Ncuhi, Hindu-Buddha, and Islam. The era of Dalu to Ncuhi was a prehistoric period that one of its traditions still persists today is the megalithic tradition that emerged during Perundagian (Bronze Age) (Syafrudin, 2016: 78). The tradition can still be seen in Dompu in general and Doro Bata in particular where the conical hill rocks was backfilled and made into terraces.
The tomb of Sultan Syamsudin was buried on the hill, some megalithic remains were also found on the hill, using large stones as a means or media supporting the spiritual and physical life. The Ncuhi chose a high place that it will make it easy to worship by making a cult medium in the northeast direction of its settlement, close to springs, streams, and having a spatial wisdom called as Lekadana. Lekadana is local wisdom in the selection of settlement land based on capacity, hydrological conditions, and others (Tim Penelitian, 2018: 22-23). At that time, Ncuhi house became the place where all the instructions were directed in the life-order of society. Ncuhi house always choose a high area, usually on a hill or plateau. It is the place where the spirits of the ancestors live, surrounded by the resident's house (Syafrudin, 2016: 87). This is apparent in the settlement of the supporting the site, where the residential area is located around the site of Doro Mpana, Waru Kali, Sambi Tangga and surrounding areas, because in this area it was also found a brick structure that is similar to the bricks found in Doro Bata site, as well as other findings in the form of earthenware fragments.

In addition to high places selection, the selection of residential location near the springs and rivers in the establishment of Doro Bata Site seems also based on the belief in the ancestral spirits and natural forces. This kind of belief has been rooted in the Ncuhi period that inhabits some places as considered sacred by the people, which directly affect the people's lives especially in maintaining health, safety, and fortune. These places are springs, estuaries, rivers, and shorelines, all of which are believed to be inhabited by ancestral spirits. In a certain radius around springs, estuaries, river banks or beachfront, they should not be used for building and crowded activities. The space is sacred and becomes an imaginary space (Syafrudin, 2016: 100-101).

At this point, the existence of Ncuhi (chief of the tribe) is very influential, as it is believed to have the ability and special sciences, thus it is believed as the incarnation of ancestral spirits or Parafu. Ncuhi has a role as a community leader, which regulates the life order of society at that time. Ncuhi itself determines when the planting period begins, offering ceremony, as well as sando (healer). Because of its role, the uma ncuhi (house of ncuhi) resides in the middle of residential area, surrounded by the resident houses, as well as cultivation area and forests. The high place selection is in accordance with the beliefs and faith of the time, that the high place is a protected place as it is the residence of ancestral spirits, protected from the attacks of wild animals or enemies, easy to observe the surrounding area, and safe from the weather (Syafrudin, 2016: 102).

Such local wisdom is thought to be the basis of consideration in the selection of the settlement area at Doro Bata Site, by balancing physical and spiritual needs 
that the support community can live prosperously. The concept of selection of this settlement area continues to gain the influence of Indian culture even to the influence of Islam in this site.

\section{Utilization Period of Doro Bata Site}

Djafar (2012: 58) described that the Sumbawa archipelago in this case in Bima there are some archaeological relics that represent the influence of Indian culture. These relics include two relief statues namely the statue of Ganesha and the Buddha Amitaba, the phallus (lingga), and some carvings of stupa reliefs on the cave wall found in a cave near Batupahat, Bima, which by the surrounding population called as Wadupaa. Regarding the date from this site, it is clearly unknown. The only relative dating that can be put forward is from the paleography of inscriptions carved into stone walls. According to Boechari as quoted by Chambert-Loir, the script is like that of the $6^{\text {th }}-7^{\text {th }}$ century. This form of script is also found on the Batu Pait Site (Nanga Mahap, West Kalimantan). The similarity of other forms that can be used as a comparison of the dating is a form of chattra (umbrella) that resembles the shape of fish spines. This form of chattra is also found on the Batu Pait Site (Chambert-Loir, 1985: 51; Utomo, 2018: 3).

In addition there is also Inscription of Wadu Tunti (Slate). This epigraph was inscribed on a large rock, in the area of Bolo, Bima. This inscription was engraved with ancient Javanese script and derived from the time around 1350 - 1400. On the other side of this inscription stone, there is also a sculpture in the form of a relief depicting a scene of four figures of divine beings with a tiger, and a figure in the middle that describes God Shiva. The relief was set in Hinduism. Djafar suspected that the influence of Indian culture only emerged in this area around the 14th century, and perhaps this is due to Majapahit political influence during the reign of Hayam Wuruk with Patih Gadjah Mada.

Muljana described concerning the islands to the east of Java, first called Bali Island, which was subdued in $1343 \mathrm{AD}$, the next one was the island of Lombok or Gurun, which is inhabited by the Sasak tribe. Both islands until now reflect the strong influence of Majapahit, that Majapahit control over Bali and Lombok is inevitable. Dompo city (Dompu now) is located on Sumbawa Island, according to Nāgarakrtāgama pupuh 72/2-3 and Pararaton, as subdued by the Majapahit army under the command of Mpu Nala in 1357 AD. The discovery of the 14th century Javanese plaque on the island of Sumbawa strengthened the preaching of Nāgarakrtāgama and Pararaton above, that Java's domination of Sumbawa Island can no longer be doubted. The charter was the only one ever found in the archipelago outside Java. Apparently, Dompo was made into a stepping stone for Majapahit to take control of the other small islands in the east to Wanin on the west coast of Irian. Unlike in Sumatra and Kalimantan, in the eastern part of Java, except in Bali and Lombok, there are no local sagas explaining about Majapahit relations with these areas (Muljana, 2006: 161). The areas in the eastern of Java controlled by Majapahit in the mid-14th century based on pupuh 14/3 are: Bali, Badahulu, Lo Gajah, Gurun, Sukun, Taliwung, Dompo, Sapi, Gunung Api, Seram, Kadali Forest, Sasak, Bantayan, Luwuk, Makassar, Buton, Banggawi, Kunir, Galian, Salayar, Sumba, Muar (Saparua), Solor, Bima, Wandan (Banda), Ambon or Maluku, Wanin, Seran, Timor (Muljana, 2006: 161-162), contained at pupuh 14/3 72 / 3 (Muljana, 2006: 346; 388).

Based on the results of interviews with three cultural experts who master the history of Dompu which are Haji Nurdin Umar, Haji Hasan Amin, and Mohammad Chaidir, it is known that one of the areas of power suspected to be the forerunner of Dompu is the coronation place of a king by the Ncuhi located on the top of the mountain known as Tonda. This area is a hill close to the sea and the ruler at that time named Dedelanata. Formerly this area was also called as Riwo and now is well-known by Ria. In 1357 AD the center of power in Tonda precisely in Riwo was moved to Doro Bata due to the expansion of Gadjah Mada which succeeded in defeating Dedelanata (Rema, 2015: 15; 2016: 1).

After this area was conquered by Mahapatih Gajah Mada during the golden age of the $14^{\text {th }}$ century of Majapahit kingdom, the reign of Hayam Wuruk, the system of his rule became a kingdom led by sangaji which means the king (Soeryanto, 2013: 6). The occurrence of political changes instilled by Gadjah Mada followed by a change of belief system that developed at the time was Hindu-Buddha (Suantika et al., 1991: 26; Sumerata, 2014b: 230). Majapahit influence in Dompu did not last long along with the entry of new understanding of Islam that has started since the 16th century (Rachman, 2011: 34; 61). Another opinion stated by Handoko that Islam was spread by the central kingdoms as the agenda of expanding power persists. Every time the expansion of power is done, at that very moment Islam is introduced into the occupied territories (Handoko, 2009: 16). Islam entered Dompu in the 16th century, marked by a change from the royal system to the sultanate and Doro Bata was allegedly the center of power or the Dompu government until the end of the Hindu-Buddhist and early Muslim period, with Sultan Syamsudin as Dompu's first sultan in 1545 AD. At that time Islam became the official religion of Dompu Sultanate (Soeryanto, 2013: 32-33; Rema, 2015: 15; 2016: 1).

According to Suastika, this site derived from the 14th-15th century, i.e. during the glory of Majapahit 
kingdom. In the process of expansion and effort to unite the entire archipelago in accordance with the oath that was uttered by Mahapatih Gadjah Mada, namely Palapa Oath which aims to unite the archipelago. For that purpose, the conquest of the kingdoms outside of Java persists (Suastika, 2005: 9). The expansion to the Sumbawa region was done by Majapahit in 1357 AD, with the conquered areas on Sumbawa island were Bima, Dompu, and Sape. This means that the area of Sumbawa is located in three centers of power or kingdom of Bima, Dompu, and Sape. This process of conquest has brought Hindu Majapahit cultural elements to the region (Suastika, 2005: 9). As evidenced by the findings of buildings that use brick with a rather large size as the size of a brick found in the former palace of Majapahit in several sites such as the Doro Bata and Worokali Site, it can be assumed that the influence of Hindu Majapahit culture has entered Dompu area at the period (Suastika, 2005: 9).

When the influence of Majapahit Kingdom in 1357 AD on Sumbawa Island, especially Dompu affected the building models and other Hindu-Buddhist features, the building models are also reflected in those on Doro Bata Site. The evidence that supports this presumption was the discovery of a brick-shaped side frame bell, which is a brick of which one side has the semicircle shape as part of a frame (Suantika et al., 1996: 71-72). Other findings that confirmed this assumption were the findings of jars of fragments of incense, fragments of unidentified pottery, ceramics, and uang kepeng. Another greatly interesting finding was a plain and ornate tombstone surrounded by rectangular brick structure on top of Doro Bata hill as presumably tomb jirat, an indication of an Islamic burial. This confirms the assumption of Dompu cultural experts who revealed that this site was a center of power during the Hindu-Buddhist and early Islamic period. This assumption was affirmed by Raffles's opinion that in $1815 \mathrm{AD}$ due to the eruption of Mount Tambora, Bata Palace in Doro Bata was moved to the north of the Nae River, which is now located in the area of Baiturrahman Great Mosque, Dompu. At the end of the Japanese occupation, the Palace was moved again to the position of Dompu Regional General Hospital in the present day. Based on these data of Doro Bata position, it is highly significant to reveal the historical events that ever took place and developed in Dompu (Suantika et al., 1994: 25; Rema, 2016: 1; 14).

The opinion stating that Doro Bata Site was once location of the Royal Palace of Dompu was mentioned by Anthony Tully (2004) followed by Helius Sjamsuddin (2015a; 2015b). The sentence was an interpretation of Owen Phillips' traveling record received by Thomas Stamford Raffles during the eruption of Mount Tambora in $1815 \mathrm{AD}$. Anthony Tully's quote is as follows.
"The blanket of ashes was so heavy that they collapsed the roofs of the Resident's and many other dwellings in Bima and rendered them uninhabitable. The Dompu Palace at Dora Bata was also buried with ash..." (Tully, 2004).

Sjamsuddin (2015a; 2015b) then explained that Tully's opinion (2004) provided a clue related to the reason for the abandonment of Dompu Palace which originally was in Bata because it was covered with ash and could no longer be inhabited. Furthermore, Sjamsuddin stated:

"It seems Bata was once an important historical siteprobably from pre-Islamic era-the old palace (asi ntoi) located in the south of Sori Na'e (Great River) which was then moved to the north of the river. In that place was established a new palace (asi $\bar{b}$ ) (located at the Site of Masjid Raya Dompu at the present). The Tambora eruption that had "forced" this all happened and displacement of the old palace to the new one. Although unlike in Java, the administrative center moved from Central Java to East Java due to the eruption of Mount Merapi, however, in Dompu the administrative center moved from the south of Sori Na'e to the north of Sori Na'e due to the Tambora eruption" (Sjamsuddin, 2015a: 72; 2015b: 86-87).

Nonetheless, Tully's interpretation of Owen Phillips's record received by Raffles needs to be reexamined. Record of Owen Phillips did not mention explicitly the name Doro Bata (or Dora Bata, Bata, and so on) (see Raffles, 1815: 21-25; 1830: 32-33; Raffles, 1830: 248250; cf. Boers, 1995: 41-46). This led to the interpretation made by Tully could be considered having no sufficient support data to reach a conclusion that Doro Bata Site was once the location of Dompu Kingdom palace.

The interesting thing is precisely the further explanation made by Sjamsuddin. Unfortunately, Sjamsuddin's exposition did not include other sources of data on which his statement was based, apart from the statement given by Tully. Most likely, Sjamsuddin's statement was based on the expanding history of the Dompu society, which declared the location of the palace of the first Dompu Sultanate. But this statement can be presumed to have a short time interval $( \pm 200$ years $)$ thus reducing the risk of historical deviations. However, Sjamsuddin's statements are important information in the interpretation of the Doro Bata Site, but as explained earlier that the statement does not provide a clear explanation of the information sources. Considering the nature of oral history data that has interdependence between sources, Sjamsuddin's statement needs to be explored more deeply related to the sources that he used, as well as tracing information from other sources, both from the community and public figures. 


\section{CONCLUSION}

Doro Bata site based on traces of remains was terraced patio, then based on the findings of the foundation structure of the building constructed with wooden construction. This site is made to be residential area as it is supported by the natural conditions that have many wellsprings, big rivers and fertile soil, and close to the bay used as a port in the past. This site is allegedly built during the influx of Hindu influence during the Majapahit rule in Dompu in the $14^{\text {th }}$ century until the Islamic period. Utilization of the site from time to time is not new thing. It often occurs, given the same view of the location that a site is considered to be special or important as the location of the Doro Bata site in high place. This site was then allegedly abandoned in the $19^{\text {th }}$ century due to the eruption of Mount Tambora.

\section{ACKNOWLEDGEMENT}

Thank you to H. Nurdin Umar; H. Hasan Amin; Muhammad Chaidir; Syafrudin as a cultural expert and other cultural experts in Dompu District whom I cannot mention for the contribution of their thinking that the research can work well.

\section{$* * * * *$}

\section{REFERENCES}

Ambary, H. M., Tawalinuddin H., Sodie, A. C., Nurhakim, L., Surjono, Astawa, G. O., \& Putri, P. G. (1978). Penelitian Arkeologi Islam di Nusa Tenggara Barat. Denpasar: Balai Arkeologi Denpasar.

Ambarawati, A. (2007). Doro Bata dan Pemberdayaan Masyarakat. Forum Arkeologi, 20(1), 116-130.

Ambarawati, A. (2010). Arsitektur Bangunan Hindu di Dompu Perbandinganya dengan Bangunan Hindu di Jawa. Forum Arkeologi. 23(1), 108-121.

Ambarawati, A. (2011). Penelitian Situs Doro Bata, Kecamatan Dompu, Kabupaten Dompu, Nusa Tenggara Barat. Denpasar: Balai Arkeologi Denpasar.

Boers, B. (1995). Mount Tambora in 1815: A Volcanic Eruption in Indonesia and Its Aftermath. Indonesia, 60, 37-60.

Chambert-Loir, H. (1985). Cerita Asal Bangsa Jin dan Segala Dewa-Dewa. Bandung: Angkasa.

Djafar, H. (2012). Pengaruh Hindu-Buddha di Nusantara Lainnya: Daerah Bima. In E. Sedyawati, \& H. Djafar (Eds.), Indonesia dalam Arus Sejarah: Kerajaan HinduBuddha (pp. 57-58). Jakarta: PT. Ichtiar Baru Van Hoeve atas Kerjasama dengan Kementerian Pendidikan dan Kebudayaan.

Handoko, W. (2009). Dinamika Budaya Islam di Wilayah Kepulauan Maluku Bagian Selatan. Kapata Arkeologi, 5(9), 14-31.
Koentjaraningrat. (2005). Pengantar Antropologi II: pokokpokok etnografi. Jakarta: Rineka Cipta.

Muljana, S. (2006). Tafsir Sejarah Nagara Kretagama. Yogyakarta: PT. LKIS Pelangi Aksara.

Prasetyo, B. (2004). Religi Pada Masyarakat Prasejarah di Indonesia. Jakarta: Kemenbudpar, Proyek Penelitian dan Pengembangan Arkeologi.

Rachman, H. M. F. (2011). Islam di Bima Kajian Historis Era Kesultanan. Mataram: Alam Tara Learning Institut.

Raffles, L. S. (1830). Memoir of The Life and Public Services of Sir Thomas Stamford Raffles, F.R.S. \&c. Particularly in The Government of Java, 1811-1824; with Detail of The Commerce and Resources of The Eastern Archipelago, and Selections from His Correspondence. London: John Murray Publisher.

Raffles, T. S. (1815). Narrative of The Effects of The Eruption from The Tomboro Mountain, in The Island of Sumbawa, on The 11th and 12th of April 1815. Verhandelingen van het Bataviaasch Genootschap, der Kunsten en Wetenschappen Deel VIII.

Raffles, T. S. (1830). The History of Java. Volume 1. London: John Murray Publisher.

Rema, I. N., Sumerata, I. W. (2015). Penelitian Situs Doro Bata Kelurahan Kandai I, Kecamatan Dompu, Kabupaten Dompu, Nusa Tenggara Barat. Denpasar: Balai Arkeologi Bali.

Rema, I. N., Sumerata, I. W. (2016). Penelitian Situs Doro Bata Kelurahan Kandai I, Kecamatan Dompu, Kabupaten Dompu, Nusa Tenggara Barat. Denpasar: Balai Arkeologi Bali.

Simanjuntak, T., Eriawati, Y., Suhadi, M., Prasetyo, B., Harkantiningsih, N., \& Handini, R. (2008). Metode Penelitian Arkeologi. Jakarta: Pusat Penelitian dan Pengembangan Arkeologi Nasional.

Sjamsuddin, H. (2015a). Letusan Gunung Tambora Tahun 1815: Caesurae Sejarah. In M. Nursam (Ed.), Letusan Gunung Tambora 1815 (pp. 59-81). Yogyakarta: Penerbit Ombak.

Sjamsuddin, H. (2015b). Memori Pulau Sumbawa: Tentang Sejarah, Interaksi Budaya \& Perubahan Sosial-Politik di Pulau Sumbawa. Yogyakarta: Penerbit Ombak.

Soeryanto, M. A. (2013). Sejarah Kabupaten Dompu. Dompu: Pemerintah Kabupaten Dompu.

Suantika, I. W., Mahaviranata, P., Astawa, G. O., Geria, I. M. (1991). Ekskavasi Arkeologi di Situs Doro Bata, Dompu, Nusa Tenggara Barat (tahap II). Denpasar: Balai Arkeologi Denpasar.

Suantika, I. W., Ambarawati, A., Mahaviranata, P. (1994). Ekskavasi Arkeologi di Situs Doro Bata, Dompu, Nusa Tenggara Barat (tahap III). Denpasar: Balai Arkeologi Denpasar.

Suantika, I. W. (1996). Doro Bata Sebuah Bukti Pengaruh Majapahit di Nusa Tenggara Barat. Forum Arkeologi, l(1), 67-75.

Suastika, I. M. (2005). Penelitian Situs Worokali, Dompu, NTB. Denpasar: Balai Arkeologi Denpasar.

Sumerata, I. W. (2014a). Ekskavasi Struktur Bangunan di Situs Doro Bata, Kelurahan Kandai I, Kecamatan Dompu, Kabupaten Dompu, Nusa Tenggara Barat. Denpasar: Balai Arkeologi Denpasar.

Sumerata, I. W. (2014b). Jejak Peradaban Islam di Situs Doro Bata, Kabupaten Dompu, Nusa Tenggara Barat. Forum Arkeologi, 27(3), 229-238.

Sutaba, I. M. (1994). Tahta Batu Prasejarah di Bali: Telaah tentang Bentuk dan Fungsinya. Dissertation Universitas Gadjah Mada.

Syafrudin, S. (2016). Pergeseran Pola Ruang Pemukiman Berbasis Budaya Lokal Dompu Di Desa Hu'u. Dompu: Bappeda dan Litbang Kab. Dompu. 
Tim Penelitian. (2017). Penelitian Situs Doro Bata, Dompu, Nusa Tenggara Barat Tahap XV Tahun 2017. Denpasar: Balai Arkeologi Bali.

Tim Penelitian. (2018). Situs Doro Bata: Studi Bentuk, Ruang, Waktu, Fungsi dan Makna. Denpasar: Balai Arkeologi Bali.

Tully, A. (2004). Tambora: The Year Without a Summer. The Indonesian Digest.

Utomo, B. B. (2018). Peradaban di Pulau Sumbawa pada Abad ke-7-19 Masehi. In Focus Group Discussion Penelitian Arkeologi Doro Bata. Dompu: Balai Arkeologi Bali.

Vansina, J. (1985). Oral Tradition as History. Madison: The University of Wisconsin Press. 